\title{
Effect of Carrot-Juice on Exopolisaccharides and $\beta$-D Galactosidase Activity in Yogurt
}

\author{
Lilik Eka Radiati*, Firman Jaya and Heldy Oktavia \\ Animal Product Technology Department, Animal Husbandry Faculty \\ Brawijaya University, Malang 65145, Indonesia \\ *Corresponding author email: lilieks_pdi@yahoo.com/lilik.eka@ub.ac.id
}

\begin{abstract}
Carrot juice and milk were blended and fermented by culture bacteria Streptococcus thermophillus and Lactobacillus bulgaricus. Carrot juice affect significantly on lactic acid content $(1.09 \pm 0.12 \%-1.15 \pm 0.01 \%)$, $\mathrm{pH}$ value $(3.80 \pm 0.06-4.17 \pm 0.10)$, viscosity $(133 \pm 2.30 \mathrm{cP}-146 \pm 2.10 \mathrm{cP}), \beta$-carotene $(0-173.19 \pm 1.02 \mu \mathrm{g} / \mathrm{g})$, EPS $(11.90 \pm 0.50-18.00 \pm 0.40 \mathrm{mg} / 100 \mathrm{~g}), \beta$-D-galactosidase activity $(2.27 \pm 0.30-192.40 \pm 0.48 \mu / \mathrm{g})$, but did not affect significantly on bacteria number $(9.0 \pm 0.5-9.8 \pm 0.4 \log \mathrm{CFU} / \mathrm{g})$. Carrot juice increased the yogurt culture activity with increasing acidifying, $\beta$-carotene, EPS and $\beta$-D-galactosidase, suggesting that yogurt could be fortified with carrot juice.
\end{abstract}

Keywords : yogurt, carrot juice, EPS, $\beta$-galactosidase activity.

Abstrak Jus wortel dan susu dicampur dan difermentasi dengan kultur Streptococcus thermophillus dan Lactobacillus bulgaricus. Jus wortel berpengaruh nyata pada asam laktat $(1.09 \pm 0.12 \%-1.15 \pm 0.01 \%)$, nilai pH $(3.80 \pm 0.06-4.17 \pm 0.10)$, viskositas (133 $\pm 2.30 \mathrm{cP}-146 \pm 2.10 \mathrm{cP}), \beta$-karoten $(0-173.19 \pm 1.02 \mu \mathrm{g} / \mathrm{g})$, eksopolisakarida (EPS) $(11.90 \pm 0.50-18.00 \pm 0.40 \mathrm{mg} / 100 \mathrm{~g})$, aktivitas $\beta$-D-galaktosidase $(2.27 \pm 0.30-192.40 \pm 0.48 \mu / \mathrm{g})$, tetapi tidak berpengaruh nyata pada jumlah bakteri kultur $(9.0 \pm 0.5-9.8 \pm 0.4 \log \mathrm{CFU} / \mathrm{g})$. Jus wortel dapat meningkatkan aktivitas kultur dengan meningkatnya keasaman, $\beta$-catotene, EPS dan $\beta$-D-galactosidase, disarankan yogurt dapat difortifikasi dengan jus wortel.

Kata kunci : yogurt, jus wortel, EPS, aktivitas $\beta$-galaktosidase

\section{Introduction}

Milk fermented with Streptococcus thermophulus and Lactobacillus bulgaricus bacteria known as yogurt product has been redesigned as nutritional food with varieties of vegetable and fruit (Ataie-Jafari et al., 2009; Brown-Riggs, 2016). Redesigned yogurt is expected to increase consumer's satisfaction with new yogurt performance including good quality, promoting properties of viable lactic acid bacteria and $\beta$-carotene enrichment in yogurt (Amany et al., 2012). The continuing development of food design hence the utilization of carrot juice in yoghurt production had affected the variety of products as well as competitiveness in its market (Lee, and Lucey, 2010; Cliff et al., 2013).
Carrot (DaucuscarrotaLinn) is one of vegetables consumed either fresh or as carrot juice as the source of $\beta$-carotenes and vitamins $B 1, B 2$ and B3. These nutrients have a role in growth and repair of tissue, help the body to prevent microorganism infection and intoxicationactivity (Ouldali, 2011; Amany et al., 2012). Vitamins and $\beta$-carotenes deficiency is one of the nutritional problems, primarily affecting infants, children and women of childbearing age. It is caused by the insufficient and poor dietary intake of vitamin and carotenes. One way of providing food enriched with $\beta$-carotene and vitamin is with food fortification regularly consumed. Milk and milk products are good source of ionic calcium and phosphorus, but contain only 1000 IU carotens (0.6 mg) or $5.6 \mathrm{mg} / 100 \mathrm{~g}$. Fortification of milk with carrot juice contain $12000 \mathrm{IU}(7.2 \mathrm{mg} / 100$ g) would supply this nutritional need for people 
who consume dairy products (Singh et al., 2006, Kwiatkowski et al., 2015).

Fresh carrot contains lower bioavalabe $\beta$ Carotene than processed carrots (Grauwet et al., 2015). In this research, fortification $\beta$ carotenes by carrot juice into milk before pasteurization could increase the bioavailability of carotenoid level in yogurt. Carrot-juice yogurt fortified could be a $\beta$-carotens dietary carrier for women, children and teenagers. The use carrot-juice yogurt fortified has advantage due to its antibacterial and antifungal properties as well as its inhibitory effect on aflatoxin $M_{1}$ and suitable probiotic bacteria which can survive during 20-day storage at refrigerator (Daneshi et al., 2012)

Selection and appropriate carrot juice as carotene source are important for the quality of carotens-fortified yogurt and consumer acceptable (Cliff et al., 2013). Limited reports about the use of carrot juice fortified yogurt on yogurt quality especially exopolysaccharides and $\beta$-galaktosidase content encourage to carry out the research. The objective of this research determined yogurt quality, particularly on exopolisaccharide and $\beta$-D-galaktosidase activity of yogurt fortified with carrot juice.

\section{Materials and Method}

Carrot-juice preparation. Carrot juice was prepared under the method by Amany et al. (2012). Carrots were blanched in boiling water with a ratio of $1: 1 \mathrm{w} / \mathrm{v}$, for $15 \mathrm{~min}$. Then the carrots were blended in a household juicer for 4 minutes at maximum speed to get carrot juice, and the juice was frozen at $20^{\circ} \mathrm{C}$ until used.

Yogurt preparation. The experiment was carried out in Pilot Plan Laboratory of Animal Products Technology Departement, Animal Husbandry Faculty, Brawijaya University). The yogurt fortified was processed as follows: 1000 $\mathrm{mL}$ whole cow milk, $6 \%$ whey powder, and 0 , $5,10,15$ and $20 \%$ carrot juice were added respectively to each batch, then pasteurized at $72^{\circ} \mathrm{C}$ for $15 \mathrm{~min}$ and cooled until $40^{\circ} \mathrm{C}$. The mixture was inoculated with $3 \%(\mathrm{v} / \mathrm{v})$ culture $S$. thermophilusand $L$. bulgaricus (ratio 3:1 $=S t: L b$ ) and packed in jar then incubated at $40^{\circ} \pm 1^{\circ} \mathrm{C}$ for $24 \mathrm{~h}$, until $\mathrm{pH}$ value reached $4.5 \pm 0.1$ and the jars were transferred to a refrigerator $\left(4 \pm 1^{\circ} \mathrm{C}\right)$ for $48 \mathrm{~h}$ before laboratory analysis.

Acidity and $\mathrm{pH}$ value determination. Yogurt $\mathrm{pH}$ value was measured by a digital $\mathrm{pH}$ meter (Model Mettler Toledo, Germany). Yogurt acidity was determined according to titration method and based on lactic acid percentage. 10 $\mathrm{ml}$ of sample was titrated with $0.1 \mathrm{NNaOH}$ using phenolphthalein as indicator and expressed (\%w/w) (AOAC, 2002).

Viscosity determination. Yogurt viscosity was determined using a Brookfield digital viscometer (Viscometer DV III models). Apparent viscosity was based on measuring resistance to a rotating spindle no 2 to rotate velocity $60 \mathrm{rpm}$ at $4^{\circ} \mathrm{C}$. This device gives the viscosity of non-Newtonian fluids directly (cP.s) after $30 \mathrm{~s}$ (Gad et al., 2014).

Sensory evaluation. Fifteen trained panelists from the graduate students and staff members of the Animal Product Technology Department of Animal Husbandry Faculty, Brawijaya University were selected on the basis of their experience in the use and evaluation of plain and carrot yogurt. Panelists were between the age of 21 until 56 years, 4 males and 11 females. They evaluated $100 \mathrm{~g}$ portions of each yogurt sample and used a quality rating score card for evaluation of appearance, taste, flavor and texture. Sensory evaluation was carried out on the samples for overall acceptability using 5criteria (1-5 scale). Score 1 indicated poor sensory attribute and score 5 indicated excellent sensory attribute. Panel consist of 15 judges familiar with carrot juice were selected and presented with the coded samples. Panelists were instructed to rinse their mouth between samples test to avoid effects of residual flavours (Madora el al., 2016). 
$\boldsymbol{\beta}$-Carotene determination. Carotene pigment was extracted from yogurt for "Reversed phased HPLC system" as described (Anjum et al., 2008). 10g of sample was homogenized in $30 \mathrm{ml}$ of acetone and then $0.1 \%$ BHT solution in acetone was added as an antioxidant. Standard Preparation of $\beta$-carotene $(1.0 \mathrm{~g}$ enclosed in vial) was obtained from Merck. Stock solution of $\beta$-carotene was prepared by taking $10 \mathrm{mg}$ in $100 \mathrm{ml} \mathrm{n}$-hexane. The concentration of stock solution was equal to $100 \mathrm{ppm}$. The stock solution was diluted to different known concentration e.g. 20, 40 and 60ppm, dilutions were obtained in $5 \mathrm{ml}$ of each $\mathrm{n}$-hexane solutions. Each working standard solution was injected into HPLC (Shimadzu LC- 20AB) consisted of C18 column and connected with LC 250 UV/VIS detector. HPLC was calibrated by running mobile phase (Acetonitrile, dichloromethane and methanol by the ratio of $70: 20: 10$, respectively) at the rate of $2 \mathrm{ml}$ per minute. Wave length was fixed at $452 \mathrm{~nm}$. The pressure of the column was kept 1800-2000 Psi. Each standard solution $(20 \mu \mathrm{l})$ of $\beta$-carotene was injected when the injector was in load mode. The standard $\beta$-carotene peak was achieved at the retention time of 4.7 minutes $(\mathrm{Rt}=4.7)$. The concentrations of the $\beta$-carotene standards were plotted against the peak area to obtain a straight line. Sample Assay Each sample of $\beta$-carotene extract in $80 \%$ acetone was used for HPLC assay like standard; $20 \mu \mathrm{l}$ each was taken by micro liter syringe. The peak was automatically identified and quantified by comparing its retention time.

Viable culture analysis. The viable cell in yogurt fortified was determined by cultivating on synthetic culture media. The Lactobacillus bulgaricus was counted on MRS (Merck, Germany) and was incubated at $40^{\circ} \mathrm{C}$ for $48 \mathrm{~h}$. Streptococcus thermophilus was counted on M17-lactose (Merck, Germany) and was incubated at $37^{\circ} \mathrm{C}$ for $48 \mathrm{~h}$.
Crude exopolisaccharidesdetermination. Crude EPS was measured after fermentation and storage period at $4^{\circ} \mathrm{Cfor} 48 \mathrm{~h}$ by van GeelSchtten et al., (2009) method as described by Ramchandran and Shah (2009). The $50 \mathrm{~g}$ yogurt fortified was centrifuged at $11000 \times \mathrm{g}, 4^{\circ} \mathrm{C}$ for $10 \mathrm{~min}$. EPS in supernatant was precipitated with cold ethanol (1 supernatant : 2 cold ethanol) and leaf at $4^{\circ} \mathrm{C}$ for a $20 \mathrm{~h}$, then centrifuged at $11,000 \times \mathrm{g}$ for $15 \mathrm{~min}$ at $4^{\circ} \mathrm{C}$ to get EPS precipitate. The precipitate was added $20 \mathrm{~mL}$ of milli-Q water, $500 \mu \mathrm{l}$ of $80 \% \mathrm{TCA}$, and let sit at $4^{\circ} \mathrm{C}$ for $20 \mathrm{~h}$ to separate protein by centrifuging at $2000 \times \mathrm{g}$ for $15 \mathrm{~min}$ at $4^{\circ} \mathrm{C}$. The protein-free supernatant was mixed with cold ethanol (1:2) and left at $4^{\circ} \mathrm{C}$ for $20 \mathrm{~h}$ to reprecipitate the EPS. The EPS precipitates were collected by centrifuging at $2000 \mathrm{xg}$ for $15 \mathrm{~min}$ at $4^{\circ} \mathrm{C}$. The crude EPS was dried at $40^{\circ} \mathrm{C}$ and was expressed crude EPS milligrams per $100 \mathrm{~g}$ of yogurt.

$\beta-D-G a l a c t o s i d a s e$ activity determination. $\beta$-DGalactosidase activity was determined using a chromogenic substrate o-nitrophenyl- $\beta$-Dgalactopyranoside (ONPG)(Lee and Lucey, 2010). Five gram of yogurt was mixed with 4.5 $\mathrm{mL}$ of $0.2 \mathrm{M}$ phosphate buffer. The sample was shaken for $30 \mathrm{~min}$ at $4^{\circ} \mathrm{C}$ and diluted 10 -fold with $0.1 \mathrm{M}$ phosphate buffer $(\mathrm{pH} 7.0 ; 0.001 \mathrm{M}$ $\mathrm{MgSO}_{4} ; 0.05 \mathrm{M} \beta$-mercaptoethanol). One $\mathrm{mL}$ of the diluted sample was added two drops of chloroform and one drop of $0.1 \%$ SDS. The reaction assay mixture was vortexed for $10 \mathrm{~s}$ and incubated at $37^{\circ} \mathrm{C}$ until yellow color appeared (after 15-20 $\mathrm{min}$ ): the reaction was stopped quickly by adjusting the solution to $\mathrm{pH}$ 11 by adding $0.5 \mathrm{~mL}$ of $1.0 \mathrm{M} \mathrm{Na}_{2} \mathrm{CO}_{3}$. At this $\mathrm{pH}$ value the enzyme is inactivated. The samples were centrifuged at $16,266 \mathrm{~g}$ and the optical density at $420 \mathrm{~nm}$ recorded using (Spectrophotometer UV-1800 Zimadzu). The standard curve of o-nitrophenol was determined the quantitative enzyme activity. One unit of enzyme activity released $1.0 \mu$ mole 
of o-nitrophenol per min. The following formula was used:

$\beta$-D-Galactosidase (units $/ \mathrm{mL})=1000\left(\mathrm{~A}_{420} / \mathrm{tv}\right)$

Where: $\mathrm{t}$ : time of reaction in minutes, v: vol. of sample used, $A_{420}$ :Absorbance at $420 \mathrm{~nm}$

Statistic analysis. Data were obtained as mean of four replication and evaluated with analysis of variance (ANOVA) by software MINITAB 16.0 and Tukey's multiple range test was used to determine the different means between treatment. The differences were considered significant at $\mathrm{P}<0.05$.

\section{Result and Discussion}

\section{Quality of yoghurt prepared using milk-carrot juice}

The difference carrot juice $(0,5,10,15$ and $20 \%$ ) in yogurt fortified showed the difference of $S$. Thermophillus and L. bulgaricus activity are presented in Table 1. The accumulation of lactic acid at the end of milk incubation time namely $\mathrm{pH} \quad 3.80 \pm 0.06-4.17 \pm 0.10$, lactic acid $1.09 \pm 0.12 \%-1.15 \pm 0.01 \%$, viscosity $133 \pm 2.30 \mathrm{cP}-$ $146 \pm 2.10 \mathrm{cP}, \quad \beta$-carotene 0-373.19 $\pm 1.02 \mathrm{\mu g} / \mathrm{g}$. The decreasing $\mathrm{pH}$ value and increasing acidity of carrot-juice yogurt fortified were significantly different $(P<0.05)$ across sample. Lactic acid was higher accumulated at the higher concentration of carrot-juice. The accumulation of lactic acid was stimulated by carrot component such as sugar, carotene and dietary fiber (Moreira, 2016). The $20 \%$ carrot-juice had the highest acidity compared with lower carrotjuice concentration because of the carrot sugar which increased bacteria lactic acid fermentation activity (Madora et al., 2012).

Carrot-juice yogurt fortified viscosity showed the increased carrot-juice concentration decreased viscosity. The high moisture content of carrot-juice was contributed to lower viscosity and the dietary fiber type of carrot showed the limited water holding capacity, so dietary fiber appeared to decrease yogurt viscosity. According to Madora et al. (2015) yogurt consistency decreased when the total solid content was lower than $16 \%-20 \%$, indicating that yogurt viscosity decreased with lowest the fat and protein content which has a significant effect on the firmness of yogurt gel and increasing yogurt syneresis.

The $\beta$-carotene content of carrot-juice yogurt fortified increased significantly as carrot-juice increased compared to yogurt control. It indicated that $20 \%$ carrot-juice provided $373.19 \pm 1.02 \mu \mathrm{g} / \mathrm{g} \beta$-Carotene.

\section{Lactic acid bacteria}

Table 1 shows that addition of $0,5,10,15$ and $20 \%$ of carrot juice in milk did not affect significantly to the culture growth among different carrot concentrations. It was explained that the starter culture resistant to the low $\mathrm{pH}$ values which maintained to a

Tabel 1. $\mathrm{pH}$ value, acidity (\% lactic acid), viscosity (cP) and carotene content $(\mu \mathrm{g} / \mathrm{g})$, number (log $\mathrm{cfu} / \mathrm{g}$ ) of Lactic Acid Bacteria of plain and yogurt prepared from milk - carrot juice mixture

\begin{tabular}{cccccc}
\hline Carrot Juice (\%) & pH Value & $\begin{array}{c}\text { Acidity } \\
(\%)\end{array}$ & $\begin{array}{c}\text { Viscosity } \\
(\mathrm{cP})\end{array}$ & $\begin{array}{c}\beta \text {-Carotene } \\
(\mu \mathrm{g} / \mathrm{g})\end{array}$ & $\begin{array}{c}\text { Lactic Acid } \\
\text { Bacteria } \\
(\text { log cfu/g) }\end{array}$ \\
\hline 0 & $4.173^{\mathrm{a}} \pm 0.10$ & $1.097^{\mathrm{a}} \pm 0.12$ & $133^{\mathrm{a}} \pm 2.30$ & - & $9.0^{\mathrm{a}} \pm 0.5$ \\
5 & $4.123^{\mathrm{b}} \pm 0.02$ & $1.111^{\mathrm{b}} \pm 0.02$ & $142^{\mathrm{b}} \pm 2.50$ & $99.89 \pm 2.00$ & $9.8^{\mathrm{b}} \pm 1.0$ \\
10 & $4.057^{\mathrm{c}} \pm 0.12$ & $1.123^{\mathrm{b}} \pm 0.01$ & $146^{\mathrm{b}} \pm 2.10$ & $181.23 \pm 1.57$ & $9.7^{\mathrm{b}} \pm 0.2$ \\
15 & $3.807^{\mathrm{d}} \pm 0.06$ & $1.157^{\mathrm{c}} \pm 0.01$ & $138^{\mathrm{c}} \pm 1.00$ & $273.30 \pm 1.32$ & $9.8^{\mathrm{b}} \pm 0.4$ \\
20 & $3.307^{\mathrm{d}} \pm 0.06$ & $1.170^{\mathrm{c}} \pm 0.01$ & $124^{\mathrm{d}} \pm 1.00$ & $373.19 \pm 1.02$ & $9.8^{\mathrm{b}} \pm 0.4$ \\
\hline
\end{tabular}

${ }^{a-c}$ Values bearing different letter within column are significantly different at $\mathrm{P}<0.05$ 
greater extent of bacteria culture. The viability of bacteria culture yogurt batches is in agreement with findings by Bayizit et al. (2007). This study showed significant differences in the count of total lactic acid bacteria between carrot-juice fortified and unfortified yogurt, but similar total lactic acid bacteria among the carrot-juice yogurt fortified. According to Daneshi et al. (2012), during the fermentation process, $S$. thermophillus and L. bulgaricus used sugar compound of carrot juice as nutrient sources. The lactic acid bacteria characteristic as living organisms required carrot components in trace mount. Similar LAB content of carrot juice-fortified yogurts reported in the present study showed no significant $(P>0.05)$ effect on $L A B$ number among the carrot-juice yogurt fortified with 9.0 $\pm 0.5-9.8 \pm 0.4 \log$ CFU/g LAB count at the end of fermentation.

\section{Sensory properties of yoghurt prepared using milk-carrot juice}

Sensory properties of foods offer quality control criteria and with regard to sensory properties of plain and carrot juice fortified yogurt were evaluated of its appearance, taste, flavor, and texture. Table 2 shows mean scores for plain and carrot juice-fortified yogurt samples.

No significant $(P>0.05)$ difference was found except for flavor acceptance $(P<0.05)$. According to the panelists the flavor and taste of samples were pleasant and sweet, while the appearance of samples was classified as normal. The sensory properties of yogurt prepared using milk with different carrot juice concentrations become even better particularly yogurt fortified with $15 \%$ carrot juice. However, yogurt fortified with $10 \%$ carrot juice can be considered acceptable by the score of acceptability 4.51. The overall sensory quality showed decreasing score acceptance, although no bitter off-flavors of carrot-juice fortified. Pectin and other compound of carrot juice were effective controlling fermentation as cofactor of lactic acid bacteria growth (Gyawali and Ibrahim, 2016).

\section{Total exopolysaccharide and $\beta$-D-galactosidase activity}

Total exopolysaccharide and $\beta$-Dgalactosidaseactivity of yogurt (containing $S$. thermophilus and L. bulgaricus) prepared using $0,5,10,15$ and $20 \%$ carrot juice are presented in Table 3 showed that increasing carrot juice concentrations added in yogurt preparation will also increase the exopolisaccharide production and $\beta$-D-Galactosidase significantly. The organic nitrogen sources significantly exhibited the positive effect on $\beta$-galactosidase production, while beef extract and yeast extract showed a significant negative influence (Sriphannam et al., 2012). Carrot was assumed to be a significant effective nutritional factor, contained inducer compound to increase $\beta$-DGalactosidase production and their activity, such as glucose, fructose and herb component to induce gluco-fructostransilase in EPS production (Shori et al., 2013). According to Chowdhury et al. (2008), yogurt with different

Table 2. Sensory test score of plain and carrot juice fortified yogurt

\begin{tabular}{cccccc}
\hline Carrot juice (\%) & Appearance & Texture & Flavor & Taste & Total Score \\
& & & & & \\
\hline 0 & $4.13^{\mathrm{a}} \pm 0.24$ & $4.12^{\mathrm{a}} \pm 0.37$ & $4.73^{\mathrm{d}} \pm 0.45$ & $4.80^{\mathrm{a}} \pm 0.33$ & $4.46^{\mathrm{b}}$ \\
5 & $4.13^{\mathrm{a}} \pm 0.56$ & $4.11^{\mathrm{a}} \pm 0.18$ & $4.23^{\mathrm{b}} \pm 0.38$ & $4.83^{\mathrm{a}} \pm 0.18$ & $4.40^{\mathrm{b}}$ \\
10 & $4.07^{\mathrm{a}} \pm 0.33$ & $4.27^{\mathrm{a}} \pm 0.44$ & $4.57^{\mathrm{c}} \pm 0.38$ & $4.97^{\mathrm{a}} \pm 0.64$ & $4.51^{\mathrm{b}}$ \\
15 & $4.19^{\mathrm{a}} \pm 0.15$ & $4.10^{\mathrm{a}} \pm 0.44$ & $4.07^{\mathrm{a}} \pm 0.20$ & $4.87^{\mathrm{a}} \pm 0.45$ & $4.31^{\mathrm{ab}}$ \\
20 & $4.17^{\mathrm{a}} \pm 0.14$ & $4.00^{\mathrm{a}} \pm 0.45$ & $4.07^{\mathrm{a}} \pm 0.43$ & $4.80^{\mathrm{a}} \pm 0.36$ & $4.26^{\mathrm{a}}$ \\
\hline
\end{tabular}

a- Values bearing different letter within column are significantly different at $(P<0.05)$ 


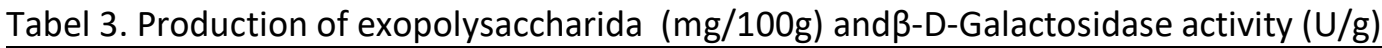

\begin{tabular}{ccc}
\hline Carrot juice (\%) & Exopolysaccharide (mg/100g) & $\beta$-D-Galactosidase activity(U/g) \\
\hline 0 & $11.90^{\mathrm{a}} \pm 0.50$ & $2.27^{\mathrm{a}} \pm 0.30$ \\
5 & $12.00^{\mathrm{b}} \pm 0.32$ & $13.50^{\mathrm{b}} \pm 0.25$ \\
10 & $18.10^{\mathrm{c}} \pm 0.40$ & $203.50^{\mathrm{d}} \pm 0.50$ \\
15 & $18.50^{\mathrm{c}} \pm 0.50$ & $198.30^{\mathrm{c}} \pm 0.48$ \\
20 & $18.00^{\mathrm{c}} \pm 0.30$ & $198.50^{\mathrm{c}} \pm 0.47$ \\
\hline
\end{tabular}

$\overline{a-b}$ Values bearing different letter within column are significantly different $\mathrm{P}<0.01$

herbs types such as tulsi (Ocimum sanctum), pudina (Mentha arvensis) and coriander (Coriandrum sativum) leaf increased $\beta$ galactosidase enzymatic activity compared to control (without any herbs). Among all herbal yogurts, tulsi yogurt showed the highest $\beta$ galactosidase activity. While their study will observe the role of other $\beta$-Galactosidase as transgalactosilase forming in or tri galactoolisaccharida (GOS). GOS is specially noted for the benefits to human health as a prebiotic to help the development of bifidobacteria and lactobacilli in the digestive tract and inhibit colon cancer, GOS production of the microbes in the fermented milk system is a more efficient alternative.

\section{Conclusion}

Carrot-juice fortified yogurts were prepared manufactured at different concentrations of carrot juice showed significant effect on yogurt quality, increased exopolisaccharide, $\beta-D$ galactosidase activity and as $\beta$-carotene source.

\section{Acknowledgement}

Authors would like to thank BOPTN Decentralization Brawijaya University for the grant and the officers in charge at Brawijaya University for the financial support.

\section{Refferences}

Anjum F, BA Khan, N Noreen, $T$ Masood and $S$ Faisal. 2008. Effect of boiling and storage on $\beta$ carotene content of different vegetables. J. life soc. sci. 6 (1):63-67.

Amany EE, A Hany, G Abou, MM Hamida, M Mousa and MM Youssef. 2012. Mixes of carrot juice and some fermented dairy products potentiality as novel functional beverages. J. Food and Nutr. Sci. (3):233-239.

Ataie-Jafari A, B Larijani, HA Majd and F Tahbaz. 2009. Cholesterol-lowering effect of probiotic yogurt in comparison with ordinary yogurt. Ann. J. Metab. 54 (1):22-27.

Bayizit AA, TÖ Yılsay and L Yılmaz. 2007. Study on the use of yoghurt, whey, lactic acid and starter culture on carrot fermentation, J. Food Nutr. Sci. 5(2):147-150

Brown-Riggs C. 2016. Nutrition and Health Disparities: The role of dairy in improving minority health outcomes. Int. J. Environ. Res. Public Health. 13 (28): 1-9in mildly to moderately hypercholesterolemic subjects. J. Ann. Nutr. Metab. (54):22-27.

Chowdhury BR, R Chakraborty and U Raychaudhuri. 2008. Study on beta-galactosidase enzymatic activity of herbal yogurt. J. Food Sci. Nutr. 59(2):116-22.

Cliff MA, L Fan, K Sanford, K Stanich, C Doucette and N Raymond. 2013. Descriptive analysis and earlystage consumer acceptance of yogurts fermented with carrot juice. J. of DairySci. 96 (7): 4160-4172

Daneshi M, MR Ehsani, SH Razavi, M Labbafi and M SheykhRezaee. 2012. Effect of cold storage on viability of probiotic bacteria in carrot fortified milk. J. Nutr. Food Sci. 2(9):1-4.

Gad AS and SHS Mohamad. 2014. Effect of hydrocolloid type on physiochemical properties of nonfat drinkable yogurt fermented with ropy and non ropy yogurt cultures. J. Comunicata Sci. 5(3):318-325.

Grauwet T, BT Kebede, RM Delgado, L Lemmens, F Manzoni, L Vervoor, M Hendrickx, JS Elmore and AV Loey. 2015. Evaluating the potential of high pressure high temperature and thermal processing on volatile compounds, nutritional and structural properties of orange and yellow carrots.J. Eur. Food Res. Technol. 240:183-198.

Kailasapathy K and K Sultana. 2003. Survival and $\beta$ D-galactosidase activity of encapsulated and free Lactobacillus acidophilus andBifidobacterium lactis in ice cream. Aust. J. Dairy Technol. (58):223-227. 
Kwiatkowski CA, M Haliniarz, B Kołodziej, E Harasim and M Tomczyńska-Mleko. 2015. Content of some chemical components in carrot (DaucuscarotaL.) roots depending on growth stimulators and stubble crops. J. Elem. 20(4):933943.

Lee WJ and JA Lucey. 2010. Formation and physical properties of yogurt. Asian-Aust. J. Anim. Sci. 23 (9):1127-1136.

Madora EP, TK Takalani and ME Mashau. 2016. Physicochemical, microbiological and sensory properties of low fat yogurt fortified with carrot powder. Int. J. Agric and Bio.Eng. 9(1):118-124.

Ouldali O, A Aoues, B Meddah, M Slimani and A Nicolas. 2011. Beneficial effects of carrot pectin against lead intoxication in wistar rats. International J. of Green Pharmacy. (6):126-130.

Ramchandran L and NP Shah. 2009. Effect of exopolysaccharides on the proteolitic and angiostensin-1 converting enzyme-inhibitory activities and textural and rheological properties of low fat yogurt during refrigerated storage. J. Dairy Sci. (92):895-906.

Singh B, PS Panesar and V Nanda. 2006. Utilization of carrot pomace for the preparation of a value added product. J. of Dairy and Food Sci. 1(1):2227.

Shori AB, AS Baba, M Misran and HW Tan. 2013. Enrichment of yogurt made from camel milk with Allium sativumanCinnamomunverum: Influence on syneresis, water holding capacity, exopolysaccharides and rheological properties. J. of veterinary and Sci. 1 (1):75-87.

Sriphannam W, K Unban, H Ashida, K Yamamoto and C Khanongnuch. 2012. Medium component improvement for $\beta$-galactosidase production by a probiotic strain Lactobacillus fermentum CM33. African Journal of Biotechnology. 11(5):11242-11251. 